\title{
Oxidation of green rust by anoxygenic phototrophic Fe(II)- oxidising bacteria
}

\author{
X. Han ${ }^{1,2,3,4,5}$, E.J. Tomaszewski², J. Sorwat ${ }^{2}$ \\ Y. Pan ${ }^{1,3,4,5}$, A. Kappler ${ }^{2 *}$, J.M. Byrne ${ }^{2}$
}

\begin{abstract}
OPEN $(0$ ACCES
Abstract

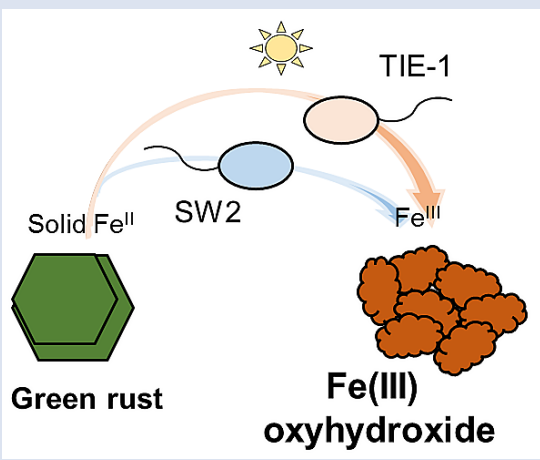

(oxyhydr)oxides and thus, this process couldropic Fe(II) oxidation of GR can contribute to the formation of Fe(III) oceans.
\end{abstract}

Received 29 May 2019 | Accepted 13 December 2019 | Published 31 January 2020

\section{Introduction}

Green rust (GR) is a mixed-valent Fe(II)/Fe(III) mineral, generally described by the formula $\left[\mathrm{Fe}(\mathrm{II})_{1-\mathrm{x}} \mathrm{Fe}(\mathrm{III})_{\mathrm{x}}(\mathrm{OH})_{2}\right]^{\mathrm{x} \cdot}[(\mathrm{x} / \mathrm{n})$ $\left.\mathrm{A}^{\mathrm{n}-}, \mathrm{mH}_{2} \mathrm{O}\right]^{\mathrm{x}-}$, with $\mathrm{A}^{\mathrm{n}-}$ denoting intercalated anions and $x$ representing the molar fraction of trivalent cations. It is a product of steel corrosion in $\mathrm{O}_{2}$-poor environments and is present in Fe-rich sediments (Trolard et al., 1997; Refait et al., 2003; Zegeye et al., 2012). Several studies have suggested GR may have been a potential precursor mineral during the precipitation of $\mathrm{Fe}$ (III) (oxyhydr)oxides and even magnetite $\left(\mathrm{Fe}_{3} \mathrm{O}_{4}\right)$ in iron formation (IF) deposition (Halevy et al., 2017; Li et al., 2017; Koeksoy et al., 2019). The majority of these Fe-rich rock formations were deposited between 2.80-1.85 Ga in the Neoarchean and Palaeoproterozoic (Klein, 2005) and typically contain iron-bearing minerals such as magnetite and hematite (Konhauser et al., 2017). However, the transformation pathways of GR into secondary mineral phases in IFs remain unclear.

Abiotic $\mathrm{O}_{2}$-driven $\mathrm{Fe}(\mathrm{II})$ oxidation and biotic anoxygenic $\mathrm{Fe}(\mathrm{II})$ photosynthesis result in $\mathrm{Fe}$ (III) mineral formation in Archean ocean analogues (Wu et al., 2014; Field et al., 2016).
These same mechanisms could also contribute to the transformation of GR into the final mineral assemblage in IFs. Microbial transformation of GR by dissolved oxygen and/or nitrate reducing bacteria can lead to the formation of a variety of Fe minerals such as magnetite, ferrihydrite $\left.\left(\mathrm{Fe}_{10} \mathrm{O}_{14}(\mathrm{OH})_{2}\right)\right)$, lepidocrocite $(\gamma-\mathrm{FeOOH})$ and goethite $(\alpha-\mathrm{FeOOH})$. All of these phases are either found in IFs, or are thought to have been precursor minerals that underwent secondary transformation to the mineral phases observed today (Legrand et al., 2004; Pantke et al., 2012; Miot et al., 2014). Yet, the most likely explanation for IF deposition in a stratified ancient ocean and the absence of Fe in Precambrian surface waters is anoxygenic Fe(II) photosynthesis, based on molecular phylogenetic evidence, $\mathrm{Fe}$ (II) oxidation rates by anoxygenic photosynthetic bacteria, and geochemical analyses from IFs (Konhauser et al., 2002; Kappler et al., 2005; Xiong, 2007). What remains unclear, is if phototrophic Fe(II) oxidisers can oxidise GR.

Here, we studied the microbial Fe(II) oxidation of carbonate GR $\left(\mathrm{CO}_{3}{ }^{2-}\right)$ by two anoxygenic phototrophic Fe(II)-oxidising bacteria: Rhodobacter ferrooxidans SW2 and Rhodopseudomonas palustris TIE- 1 . We investigated the ability of these two species to oxidise Fe(II) in GR by quantifying

\footnotetext{
1. Biogeomagnetism Group, Key Laboratory of Earth and Planetary Physics, Institute of Geology and Geophysics, Chinese Academy of Sciences, Beijing 100029, China

2. Geomicrobiology, Center for Applied Geosciences, University of Tuebingen, 72074 Tuebingen, Germany

3. France-China International Laboratory of Evolution and Development of Magnetotactic Multicellular Organisms, Chinese Academy of Sciences, Beijing 100029, China

4. Institutions of Earth Science, Chinese Academy of Sciences, China

5. University of Chinese Academy of Sciences, Beijing 100049, China

Corresponding author (email: andreas.kappler@uni-tuebingen.de)
} 
$\mathrm{Fe}(\mathrm{II})$ and total Fe in both aqueous and solid phases spec trophotometrically, and by Mössbauer spectroscopy. We also observed the cell mineral associations using SEM. Based on our results, we hypothesise that anoxygenic phototropic Fe(II) oxidation of GR could have contributed to the formation of Fe(III) (oxyhydr)oxides during Precambrian IFs deposition.

\section{Materials and Methods}

GR $\left(\mathrm{CO}_{3}{ }^{2-}\right)$ synthesis. GR $\left(\mathrm{CO}_{3}{ }^{2-}\right)$ was synthesised following the modified protocol of Bocher et al. (2004), (further details in SI). After synthesis, the initial GR was divided into separate bottles, which were washed with anoxic ultrapure $\mathrm{H}_{2} \mathrm{O}$ water (GR_water), SW2 medium (GR_SW2) and TIE-1 medium (GR_ TIE-1), respectively, in a glovebox to remove dissolved Fe(II).

Culturing medium and experimental setup. Detailed information on cultivation of SW2 and TIE-1 is provided in the SI. Before inoculation, GR_SW2, and GR_TIE-1 stock solution $(\sim 6 \mathrm{mM}$ solid $\mathrm{Fe}(\mathrm{II})$ ) were injected into the $25 \mathrm{ml}$ anoxic and sterile medium. From the stock culture, $10 \%(2.5 \mathrm{ml})$ and $20 \%(5 \mathrm{ml})$ inoculum were added to respective microcosms and incubated for 19 days at $20^{\circ} \mathrm{C}$ and $12 \mu \mathrm{mol}$ quanta $\mathrm{m}^{-2} \mathrm{~s}^{-1}$ (600 lux) with a $40 \mathrm{~W}$ tungsten incandescent light bulb. Triplicates were prepared for both SW2 and TIE-1, with an additional sterile setup containing no inoculum to confirm the absence of chemical oxidation of Fe(II)

Fe speciation analysis. For Fe(II) and total Fe (Fe(II) and $\mathrm{Fe}(\mathrm{III})$ ) analyses in both aqueous and solid phases, $1 \mathrm{ml}$ of culture slurry was centrifuged at $13400 \mathrm{rpm}$ for $10 \mathrm{~min}$. The supernatant was mixed with $1 \mathrm{M} \mathrm{HCl}$ to prevent further oxidation. The residual precipitate was dissolved in $6 \mathrm{M} \mathrm{HCl}$ within 24 hours, and further diluted with $1 \mathrm{M} \mathrm{HCl}$ to prevent $\mathrm{Fe}(\mathrm{II})$ oxidation (Porsch and Kappler, 2011). All sampling, centrifugation and dissolution steps were conducted in an anoxic glovebox $\left(100 \% \mathrm{~N}_{2}\right)$. Both Fe(II) and total Fe concentrations were quantified by the ferrozine assay (Stookey, 1970) with $\mathrm{Fe}(\mathrm{III})$ calculated as the difference between Fe(total) and Fe(II).

Mössbauer spectroscopy. For Mössbauer analysis, samples of four GR materials and final microbial oxidation products after 19 days cultivation were filtered on $0.45 \mu \mathrm{m}$ filter papers, embedded in Kapton tape in an anoxic glovebox (100 \% $\mathrm{N}_{2}$ ) and stored in anoxic glass bottles at $-20{ }^{\circ} \mathrm{C}$ until analysis. The samples were measured at $140 \mathrm{~K}$ using a ${ }^{57} \mathrm{Fe}$ Mössbauer spectrometer (WissEL) with a ${ }^{57} \mathrm{Co} / \mathrm{Rh}$ source. Spectra were fitted using the Voigt based fitting (VBF) routine in the Recoil software (University of Ottawa) (Rancourt and Ping, 1991).

Scanning electron microscopy (SEM). For SEM, culture slurry was collected and washed with ultra-pure $\mathrm{H}_{2} \mathrm{O}$. Washed samples were dropped on a $0.45 \mu \mathrm{m}$ filter paper (Fig. S-2) to dry samples quickly in the glovebox and avoid chemical oxidation
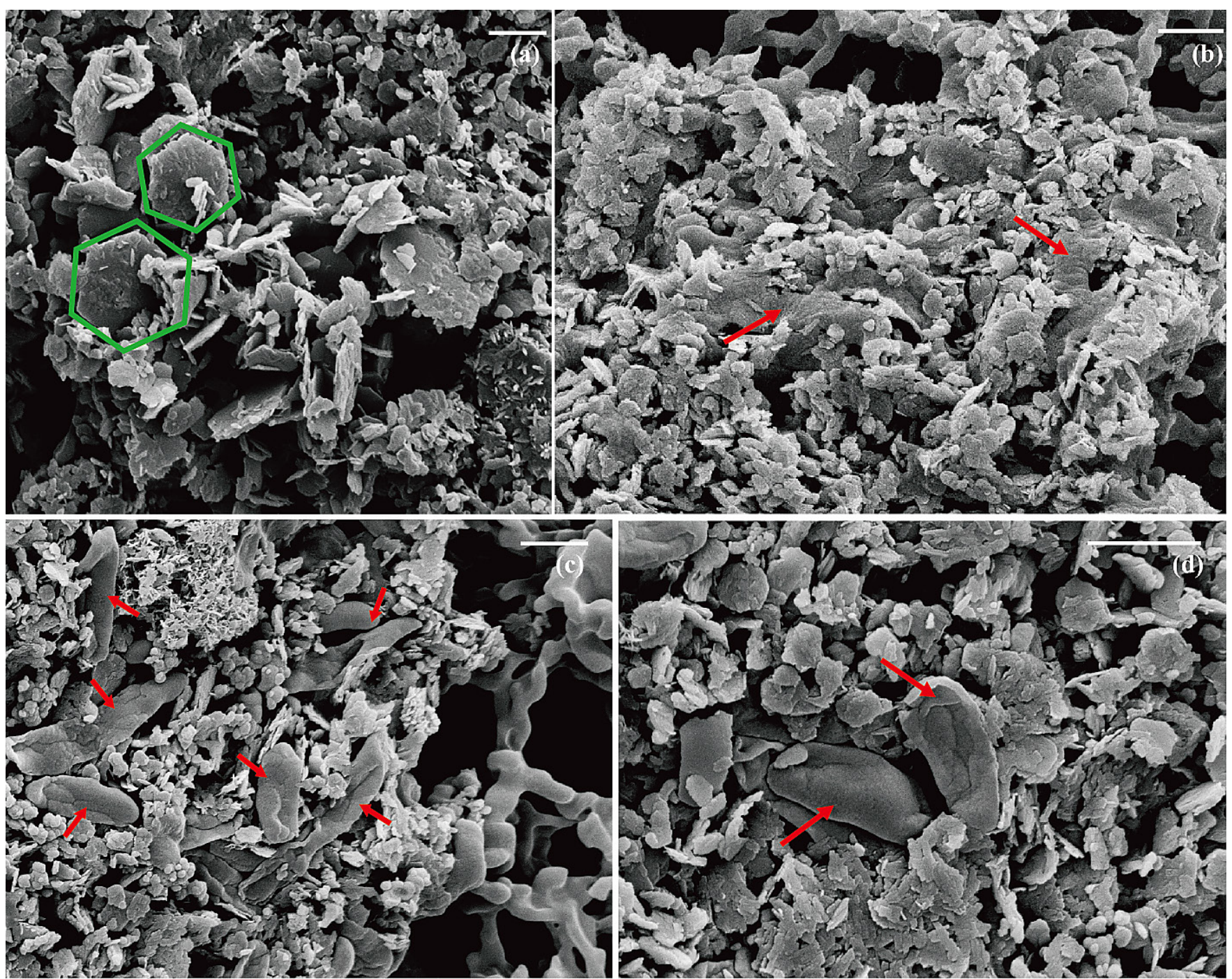

Figure 1 Scanning electron microscopy (SEM) images of (a) GR_SW2 starting material, (b) SW2 culture suspension with GR, and $(c, d)$ TIE-1 culture suspension with GR after 13 days cultivation. All scale bars in figures are $1 \mu \mathrm{m}$. The green hexagons are GR. The red arrows point to the cells. 
of samples. Dried samples were mounted onto aluminum stubs using double sided carbon tape, and coated with a $12 \mathrm{~nm}$ platinum (Baltec SCD005). Micrographs were collected using a JEOL JSM-6500F field emission SEM with a Schottky field emitter, acceleration voltage $5 \mathrm{kV}$, working distance $10 \mathrm{~mm}$.

\section{Results and Discussion}

GR properties. Chemical dissolution followed by a spectrophotometric ferrozine assay (Stookey, 1970) showed that there was almost no $\mathrm{Fe}$ (II) $(<0.16 \mathrm{mM})$ in the aqueous phase for the four GR materials after washing (Table 1). It should be noted, however, that more Fe was removed from initial GR by washing with SW2 and TIE-1 medium than by water, and that the $\mathrm{pH}$ of GR_SW2 and GR_TIE-1 were lower than initial GR and GR_ water. Nevertheless, the $\mathrm{Fe}(\mathrm{III}) / \mathrm{Fe}(\mathrm{II})$ molar ratio in the solid phase of the four GR materials was the same ( 0.3), which was consistent with Mössbauer spectroscopy (Fig. S-1). Mössbauer spectroscopy of the initial materials indicated the presence of
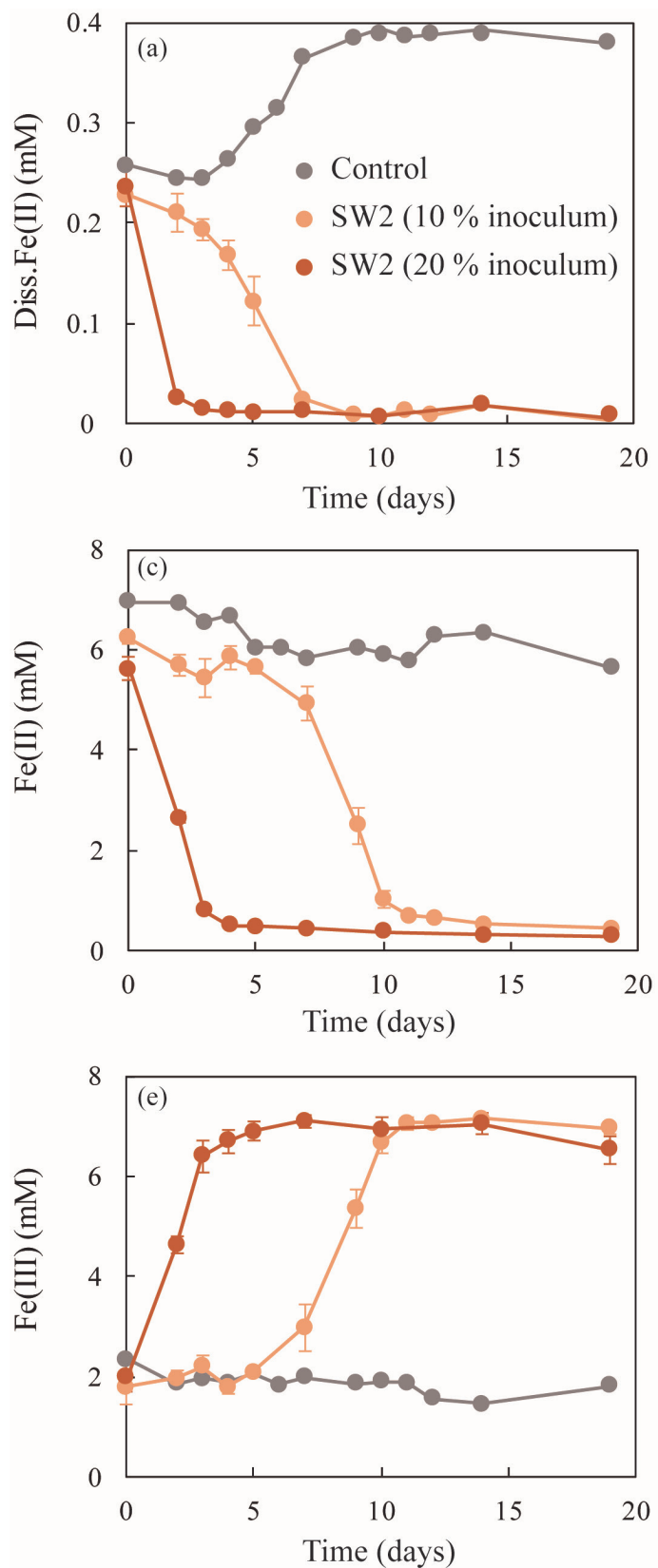

a minor sextet phase for initial GR, GR_water and GR_TIE-1, likely goethite, and resulted from partial oxidation (3.3-13.1\%) of GR before inoculation of bacteria. SEM showed hexagonal crystals of GR_SW2 with diameter of $\sim 1 \mu \mathrm{m}$ (Fig. 1a), before and after washing, implying that washing with medium did not change the mineral morphology of GR.

Table 1 Fe concentration and $\mathrm{pH}$ of four GR materials: Initial GR, GR_water, GR_SW2 and GR_TIE-1.

\begin{tabular}{|c|c|c|c|c|c|c|c|}
\hline \multirow{2}{*}{ GR materials } & \multirow{2}{*}{\begin{tabular}{|c|}
$\begin{array}{c}\text { Aqueous } \\
\text { phase }\end{array}$ \\
$\begin{array}{l}\mathrm{Fe}(\mathrm{II}) \\
(\mathrm{mM})\end{array}$ \\
\end{tabular}} & \multicolumn{3}{|c|}{ Solid phase } & \multirow{2}{*}{$\begin{array}{l}\text { Total } \\
\text { Fe(II) } \\
\text { (mM) }\end{array}$} & \multirow{2}{*}{$\begin{array}{c}\text { Total } \\
\text { Fe } \\
(\mathrm{mM})\end{array}$} & \multirow{2}{*}{$\mathrm{pH}$} \\
\hline & & $\begin{array}{l}\mathrm{Fe}(\mathrm{II}) \\
(\mathrm{mM})\end{array}$ & $\begin{array}{c}\mathrm{Fe}(\mathrm{III}) \\
(\mathrm{mM})\end{array}$ & $\begin{array}{c}\mathrm{Fe}(\mathrm{III}) \\
\mathrm{Fe}(\mathrm{II})\end{array}$ & & & \\
\hline Initi & 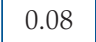 & 140.72 & 41.71 & .30 & 140.80 & 182.51 & 9.72 \\
\hline GR_w & 0.03 & 130.15 & 39.04 & 0.30 & 130.18 & 169.22 & 9.69 \\
\hline GR_SW2 & 0.11 & 108.31 & 31.88 & 0.29 & 108.42 & 140.30 & 8.69 \\
\hline GR_TIE-1 & 0.16 & 107.85 & 32.63 & 0.30 & 108.01 & 140.64 & 8.55 \\
\hline
\end{tabular}
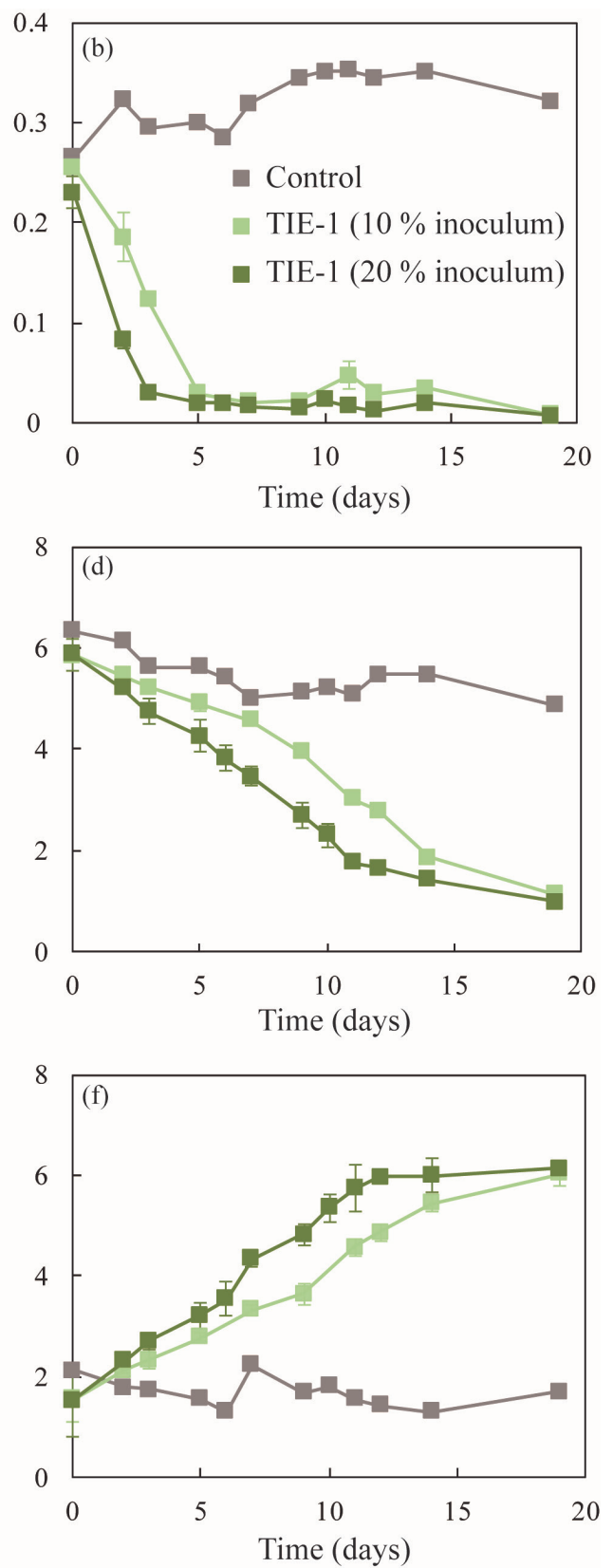

Figure 2 (a,b) Dissolved Fe(II), (c,d) Fe(II) in solid phase, (e,f) Fe(III) in solid phase at different time points during GR oxidation by SW2 and TIE-1. Error bars indicate standard deviation of three biological replicates. 
GR oxidation rates and extent. Microcosms were set up containing GR minerals with $\sim 6 \mathrm{mM} \mathrm{Fe}$ (II) and either strain SW2 or TIE-1. SW2 with $10 \%$ or $20 \%$ inoculum finished GR oxidation in 11 days or 4 days, and oxidised $89 \%$ or $91 \%$ solid Fe(II), respectively. The GR oxidation rate by SW2 with $20 \%$ inoculum $(1.33 \mathrm{mM} /$ day) is more than twice as high as that with $10 \%$ inoculum $(0.52 \mathrm{mM} /$ day $)$. Conversely, TIE-1 with $10 \%$ or $20 \%$ inoculum oxidised $81 \%$ or $83 \% \mathrm{Fe}(\mathrm{II})$ at similar rates (0.26-0.27 mM/day) during 19 days cultivation (Fig. 2). For both SW2 and TIE-1, there was still some Fe(II) left (9-19\%) in the solid phase. However, Mössbauer spectroscopy could not conclusively identify the Fe(II) phase. The $\mathrm{Fe}(\mathrm{II})$ oxidation rate determined for strain SW2 is consistent with a previous study, which hypothesised that anoxygenic phototrophs provide the most likely explanation for IF deposition in a stratified ancient ocean and the absence of Fe in Precambrian surface waters (Kappler et al., 2005). Although we observed slight increases in dissolved Fe(II) (0.05-0.12 mM) and a decrease in solid phase Fe(II) (1.34-1.46 mM) in abiotic controls, this suggests only minor changes in Fe speciation including GR dissolution but not abiotic oxidation of GR.

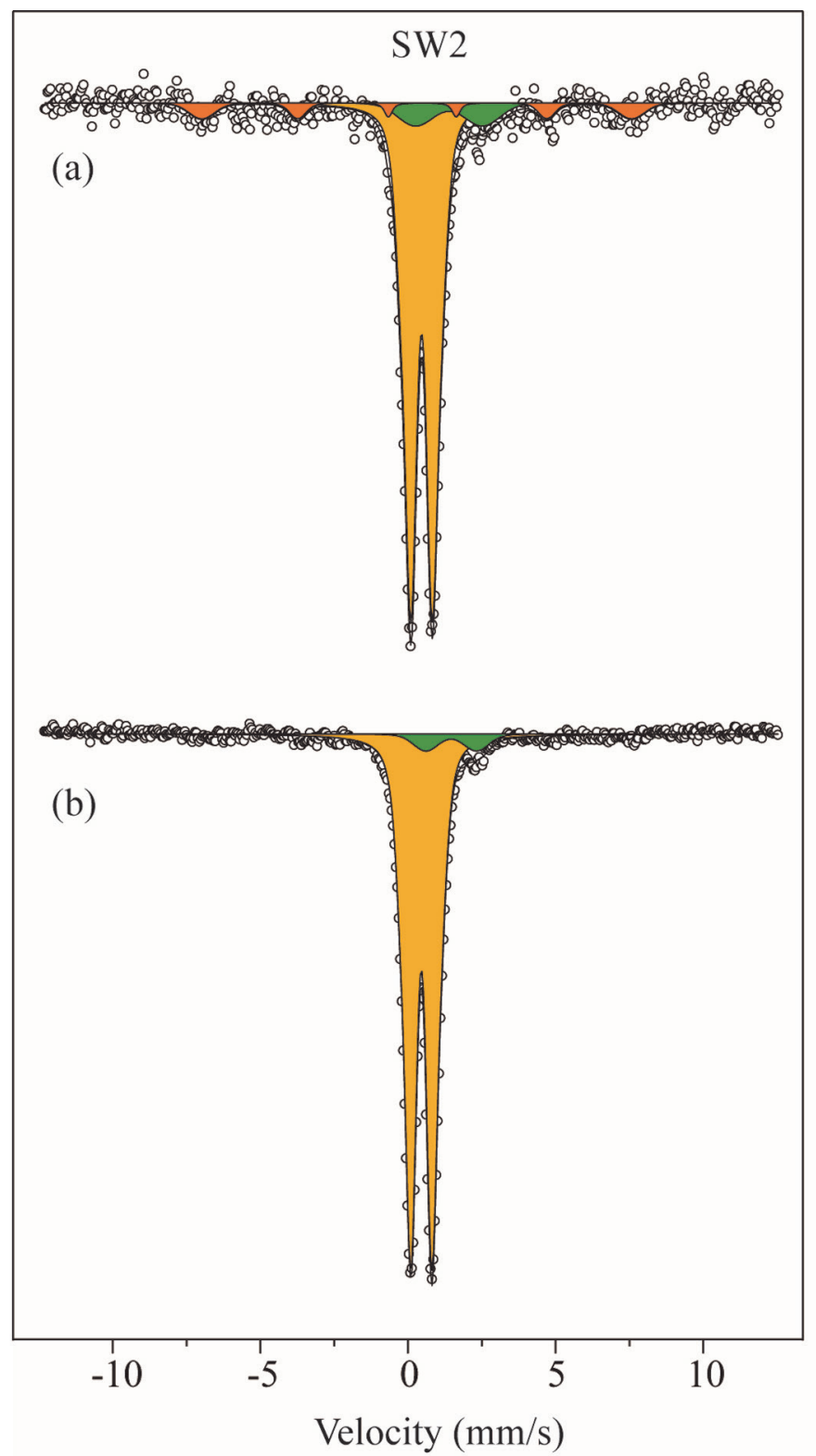

GR oxidation products and oxidation mechanism. Mössbauer spectroscopy results showed both SW2 and TIE-1 oxidised the GR to a short range ordered Fe(III) oxyhydroxide phase. Based on hyperfine parameters, this phase is most likely to be ferrihydrite (Murad and Cashion, 2004) (Fig. 3). The minor sextet observed in the spectra of the oxidation products is likely indicative of goethite. Additionally, there was less Fe(II) remaining in the solid phase for SW2 compared to TIE-1, which is consistent with the spectrophotometric results. We observed that the rate of GR-Fe(II) oxidation was faster for SW2 than TIE-1, however, the exact reason for this is currently unknown. It has been previously shown that both strains have different mechanisms for Fe(II) oxidation i.e. they both use different proteins, and that affects the rate at which they are able to oxidised complexed Fe(II) (Peng et al., 2019a,b). Potentially, this difference in proteins is responsible for the differences we saw here. For abiotic $\mathrm{O}_{2}$-driven GR oxidation, where GR and dissolved oxygen are the reactants, $\mathrm{FeOOH}$ is the mineral end product and $\left[\left(\mathrm{Fe}^{\mathrm{II}}\right)_{2}\left(\mathrm{Fe}^{\mathrm{III}}\right)\right]$ the intermediate species. The transformation is a dissolution-oxidation-precipitation reaction (Legrand et al., 2004). The dissolved

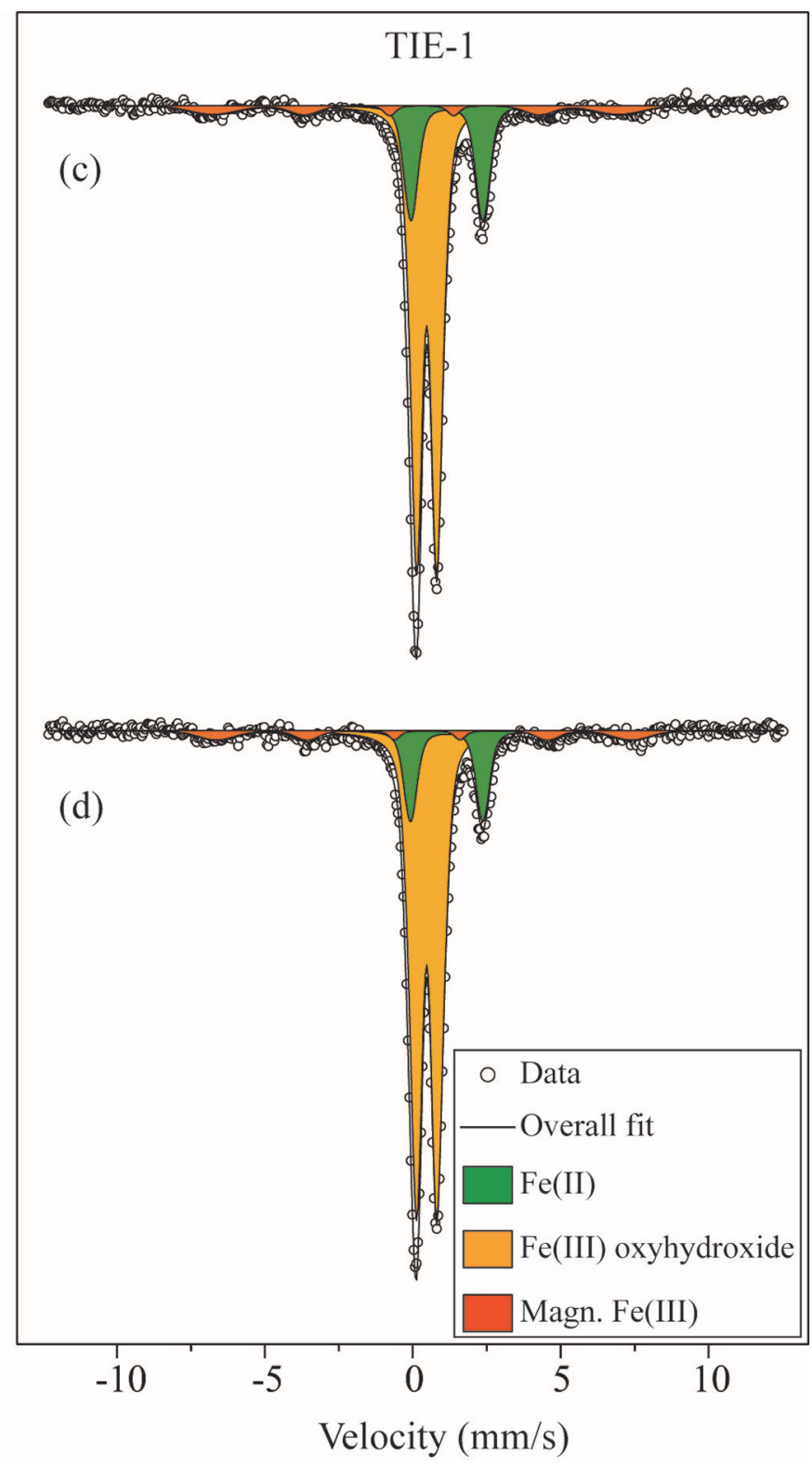

Figure 3 Mössbauer spectroscopy data of the minerals produced by oxidation of GR by the phototrophic Fe(II)-oxidising strains SW2 (10\% inoculum (a) and $20 \%$ inoculum (b)) and TIE-1 (10 \% inoculum (c) and $20 \%$ inoculum (d)), respectively. Magn. Fe(III) corresponds to a magnetically ordered Fe mineral. 
$\left[\left(\mathrm{Fe}^{\mathrm{II}}\right)_{2}\left(\mathrm{Fe}^{\mathrm{III}}\right)\right]$ species, which is in equilibrium with the GR mineral particles, is released when GR minerals dissolve as illustrated by the following schematic reaction Eq. 1 (Misawa et al., 1973, 1974). In our microbial microcosm experiments with GR, the SW2 and TIE1 strains can either oxidise structural Fe(II) in GR, or these strains promote GR dissolution to $\mathrm{Fe}$ (II)-Fe(III) complexes or colloids, and then oxidise these more bioavailable species immediately. Obviously no complete dissolution of the GR took place since there were almost no aqueous Fe(III) and Fe(II) species $(<0.03 \mathrm{mM})$ detected for SW2 and TIE-1 after 7 days and 5 days, respectively. This suggests that the reaction proceeds following Eq. 1 and Eq. 2:

$$
\begin{aligned}
& {\left[\mathrm{Fe}_{4}^{\mathrm{II}} \mathrm{Fe}_{2}^{\mathrm{III}}(\mathrm{OH})_{12}\right]\left[\mathrm{CO}_{3}, 2 \mathrm{H}_{2} \mathrm{O}\right] \stackrel{\text { dissolution/precipitation }}{\longleftarrow}} \\
& 2\left[\left(\mathrm{Fe}^{\mathrm{II}}\right)_{2}\left(\mathrm{Fe}^{\mathrm{III}}\right)\right]+12 \mathrm{OH}^{-}+\mathrm{CO}_{3}^{2-}+2 \mathrm{H}_{2} \mathrm{O} \quad \text { Eq. } 1 \\
& 2\left[\left(\mathrm{Fe}^{\mathrm{II}}\right)_{2}\left(\mathrm{Fe}^{\mathrm{III}}\right)\right]^{7+}+\mathrm{HCO}_{3}^{-}+10 \mathrm{H}_{2} \mathrm{O} \stackrel{\text { hv }}{\rightarrow} 6 \mathrm{FeOOH}+\left(\mathrm{CH}_{2} \mathrm{O}\right)+13 \mathrm{H}^{+} \\
& \text {Eq. } 2
\end{aligned}
$$

Despite reported studies on oxidation of GR by nitrate reducing Fe(II)-oxidising bacteria (Pantke et al., 2012; Etique et al., 2014; Miot et al., 2014), the question remains whether phototrophic $\mathrm{Fe}(\mathrm{II})$-oxidising bacteria can access lattice $\mathrm{Fe}(\mathrm{II})$ in GR. Genetic studies have shown that pioABC or foxEYZ operons are involved in electron uptake from Fe(II) by TIE-1 and SW2, respectively (Croal et al., 2007; Jiao and Newman, 2007). Although SW2 could not oxidise solid phase $\mathrm{Fe}(\mathrm{II})$ mineral phases such as vivianite, magnetite or pyrite (Kappler and Newman, 2004), strain TIE-1 can access not only dissolved $\left[\mathrm{Fe}^{2+}{ }_{(\mathrm{aq})}\right]$ or complexed $\mathrm{Fe}(\mathrm{II})$ [e.g., $\mathrm{Fe}(\mathrm{II})$-nitrilotriacetic acid], but also Fe(II) in the mixed-valent Fe(II)-Fe(III) mineral magnetite (Byrne et al., 2015) as well as poised electrodes (Bose et al., 2014). Follow up studies have shown that for magnetite oxidation by TIE-1, a direct surface-mineral contact mechanism might be required (Byrne et al., 2016). Since we did not fix cells for electron microscopy analyses, most SW2 cells appeared flattened or were difficult to distinguish from minerals (Fig. 1b), but many TIE-1 cells which have a length of $\sim 1 \mu \mathrm{m}$ and direct contact with the minerals could be observed (Fig 1c,d). In our study, the initial Fe(II)/Fe(III) ratio of GR was six times higher than magnetite, suggesting that if solid Fe(II) can be accessed by the bacteria, GR could potentially act as an electron donor for phototrophic Fe(II)-oxidisers. Moreover, the high solubility of GR phases could cause the Fe(II) in GR to be more bioavailable than structural Fe(II) in magnetite to phototrophic $\mathrm{Fe}(\mathrm{II})$-oxidising bacteria through pioABC or foxEYZ operons, either when the cells are in direct contact with the minerals or when the GR is undergoing partial dissolution.

Implications for iron mineral deposition. The deposition of Precambrian rocks has mostly been interpreted as resulting from abiotic or microbial oxidation of dissolved Fe(II) (Posth et al., 2013, 2014) or by oxidation of Fe(II)-containing minerals such as green rust by abiotic processes (Li et al., 2017) and/or nitrate reducing iron-oxidising bacteria (Miot et al., 2014). Our present study shows that anoxygenic phototrophic $\mathrm{Fe}(\mathrm{II})$-oxidising bacteria could also play a role in oxidation of green rust and potentially the deposition of Fe(III) (oxyhydr) oxide minerals in IFs. This work supports previous claims that anoxygenic phototrophic Fe(II)-oxidising bacteria could have played a significant role in IF deposition by promoting the precipitation of $\mathrm{Fe}$ (III) (oxyhydr)oxides (Posth et al., 2008; Czaja et al., 2013). Here, we present evidence that anoxygenic phototrophic Fe(II)-oxidising bacteria can oxidise GR to a short range ordered Fe(III) oxyhydroxide in freshwater media, further highlighting the potential role of these microorganisms in the genesis of minerals in IFs in ancient environments.

\section{Supplementary Information}

The Supplementary Information contains additional Materials and Methods, Tables with Fe(II), Fe(III), Fe(tot) concentrations over time in microbial cultures and Mössbauer spectroscopy hyperfine parameters, as well as figures for Mössbauer spectrum of four GR materials and SEM image of $0.45 \mu \mathrm{m}$ filter paper.

\section{Acknowledgements}

This research was funded by the German Research Foundation (DFG) under grant no. KA 1736/39-1. Yongxin Pan was supported by grant of the National Natural Science Foundation of China (41621004). We also thank China Scholarship Council (CSC) for the financial support to X.H.

Editor: Liane G. Benning

\section{Additional Information}

Supplementary Information accompanies this letter at http:// www.geochemicalperspectivesletters.org/article2004.

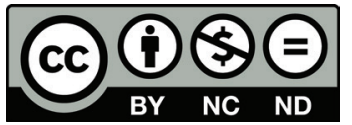

This work is distributed under the Creative Commons Attribution Non-Commercial No-Derivatives 4.0 License, which permits unrestricted distribution provided the original author and source are credited. The material may not be adapted (remixed, transformed or built upon) or used for commercial purposes without written permission from the author. Additional information is available at http://www.geochemicalperspectivesletters.org/ copyright-and-permissions.

Cite this letter as: Han, X., Tomaszewski, E.J., Sorwat, J., Pan, Y., Kappler, A., Byrne, J.M. (2020) Oxidation of green rust by anoxygenic phototrophic Fe(II)-oxidising bacteria. Geochem. Persp. Let. 12, 52-57.

\section{References}

Bocher, F., GéHin, A., Ruby, C., Ghanbaja, J., Abdelmoula, M., Génin, J.-M.R. (2004) Coprecipitation of Fe(II-III) hydroxycarbonate green rust stabilised by phosphate adsorption. Solid State Sciences 6, 117-124.

Bose, A., Gardel, E.J., Vidoudez, C., Parra, E.A., Girguis, P.R. (2014) Electron uptake by iron-oxidizing phototrophic bacteria. Nature Communications 5, 3391

Byrne, J.M., Klueglein, N., Pearce, C., Rosso, K.M., Appel, E., KAPPLER, A. (2015) Redox cycling of Fe(II) and Fe(III) in magnetite by Fe-metabolizing bacteria. Science 347, 1473.

Byrne, J.M., VAn Der LaAn, G., Figueroa, A.I., QAfokU, O., WANG, C., Pearce, C.I., Jackson, M., Feinberg, J., Rosso, K.M., Kappler, A. (2016) Size dependent microbial oxidation and reduction of magnetite nano-and micro-particles. Scientific Reports 6, 30969.

Croal, L.R., JiaO, Y., NeWMAN, D.K. (2007) The fox operon from Rhodobacter strain SW2 promotes phototrophic Fe (II) oxidation in Rhodobacter capsulatus SB1003. Journal of Bacteriology 189, 1774-1782.

Czaja, A.D., Johnson, C.M., Beard, B.L., Roden, E.E., Li, W., MoorBATH, S. (2013) Biological Fe oxidation controlled deposition of banded iron formation in the ca. 3770Ma Isua Supracrustal Belt (West Greenland). Earth and Planetary Science Letters 363, 192-203.

Etique, M., Jorand, F.P.A., Zegeye, A., Grégoire, B., Despas, C., Ruby, C. (2014) Abiotic Process for Fe(II) Oxidation and Green Rust Mineralization Driven by a Heterotrophic Nitrate Reducing Bacteria (Klebsiella mobilis). Environmental Science \& Technology 48, 3742-3751. 
Field, E.K., Kato, S., Findlay, A.J., MacDonald, D.J., Chiu, B.K., LUTHER, G.W., CHAN, C.S. (2016) Planktonic marine iron oxidizers drive iron mineralization under low-oxygen conditions. Geobiology 14 499-508.

Halevy, I., Alesker, M., Schuster, E.M., Popovitzbiro, R., Feldman, Y. (2017) A key role for green rust in the Precambrian oceans and the genesis of iron formations. Nature Geoscience 10.

JiaO, Y., Newman, D.K. (2007) The pio operon is essential for phototrophic Fe (II) oxidation in Rhodopseudomonas palustris TIE-1. Journal of Bacteriology 189, 1765-1773.

KappleR, A., NeWman, D.K. (2004) Formation of Fe(III)-minerals by Fe(II)-oxidizing photoautotrophic bacteria 1. Geochimica et Cosmochimica Acta 68, 1217-1226.

Kappler, A., Newman, D.K., Konhauser, K.O., Pasquero, C. (2005) Deposition of banded iron formations by anoxygenic phototrophic Fe(II)-oxidizing bacteria. Geology 33, 865

KLEIN, C. (2005) Some Precambrian banded iron-formations (BIFs) from around the world: Their age, geologic setting, mineralogy, metamorphism, geochemistry, and origins. American Mineralogist 90, 1473.

Koeksoy, E., Sundman, A., Byrne, J.M., Lohmayer, R., Planer-FriedRICH, B., Halevy, I., Konhauser, K.O., Kappler, A. (2019) Formation of green rust and elemental sulfur in an analogue for oxygenated ferro-euxinic transition zones of Precambrian oceans. Geology 47, 211-214

Konhauser, K.O., Hamade, T., Raiswell, R., Morris, R.C., Ferris, F.G., Southam, G., CAnfield, D.E. (2002) Could bacteria have formed the Precambrian banded iron formations? Geology 30, 1079.

Konhauser, K.O., Planavsky, N.J., Hardisty, D.S., Robbins, L.J., Warchola, T.J., Haugaard, R., Lalonde, S.V., Partin, C.A., OONK, P.B.H., TsikOS, H., LYONS, T.W., BEKKER, A., JOHNSON, C.M. (2017) Iron formations: A global record of Neoarchaean to Palaeoproterozoic environmental history. Earth-Science Reviews 172, 140-177.

Legrand, L., Mazerolles, L., Chaussé, A. (2004) The oxidation of carbonate green rust into ferric phases:solid-state reaction or transformation via solution11Associate editor: G. Sposito. Geochimica et Cosmochimica Acta 68, 3497-3507.

LI, Y.L., Konhauser, K.O., ZHAI, M. (2017) The formation of magnetite in the early Archean oceans. Earth and Planetary Science Letters 466, $103-114$

Miot, J., Li, J., Benzerara, K., Sougrati, M.T., Ona-Nguema, G., Bernard, S., Jumas, J.C., GuYot, F. (2014) Formation of single domain magnetite by green rust oxidation promoted by microbial anaerobic nitrate-dependent iron oxidation. Geochimica et Cosmochimica Acta 139, 327-343.

Misawa, T., Hashimoto, K., Shimodaira, S. (1973) Formation of $\mathrm{Fe}(\mathrm{II}) 1 \mathrm{Fe}(\mathrm{III}) 1$ intermediate green complex on oxidation of ferrous ion in neutral and slightly alkaline sulphate solutions. Journal of Inorganic and Nuclear Chemistry 35, 4167-4174.

Misawa, T., Hashimoto, K., Shimodaira, S. (1974) The mechanism of formation of iron oxide and oxyhydroxides in aqueous solutions at room temperature. Corrosion Science 14, 131-149.

Murad, E., CAshion, J. (2004) Iron oxides. In: Murad, E., Cashion, J. (Eds.) Mössbauer spectroscopy of environmental materials and their industrial utilization. Springer, Boston, MA, 159-188.

Pantke, C., Obst, M., Benzerara, K., Morin, G., Ona-Nguema, G Dippon, U., Kappler, A. (2012) Green Rust Formation during Fe(II) Oxidation by the Nitrate-Reducing Acidovorax sp. Strain BoFeN1. Environmental Science \& Technology 46, 1439-1446.

Peng, C., Bryce, C., Sundman, A., Borch, T., Kappler, A. (2019a) Organic Matter Complexation Promotes Fe(II) Oxidation by the Photoautotrophic Fe(II)-Oxidizer Rhodopseudomonas palustris TIE-1. ACS Earth and Space Chemistry 3, 531-536.

Peng, C., Bryce, C., Sundman, A., Kappler, A. (2019b) Cryptic Cycling of Complexes Containing Fe(III) and Organic Matter by Phototrophic $\mathrm{Fe}(\mathrm{II})-\mathrm{Oxidizing} \mathrm{Bacteria.} \mathrm{Applied} \mathrm{and} \mathrm{Environmental} \mathrm{Microbiology} \mathrm{85,}$ e02826-18.

Porsch, K., KappleR, A. (2011) FeII oxidation by molecular O2 during HCl extraction. Environmental Chemistry 8, 190-197.

Posth, N.R., Hegler, F., Konhauser, K.O., Kappler, A. (2008) Alternating $\mathrm{Si}$ and $\mathrm{Fe}$ deposition caused by temperature fluctuations in Precambrian oceans. Nature Geoscience 1, 703-708.

Posth, N.R., Konhauser, K.O., Kappler, A. (2013) Microbiologica processes in banded iron formation deposition. Sedimentology 60 1733-1754.

Posth, N.R., CAnfield, D.E., Kappler, A. (2014) Biogenic Fe(III) minerals: From formation to diagenesis and preservation in the rock record Earth-Science Reviews 135, 103-121.
RANCOURT, D.G., PING, J.Y. (1991) Voigt-based methods for arbitrary-shape static hyperfine parameter distributions in Mössbauer spectroscopy. Nuclear Instruments and Methods in Physics Research Section B: Beam Interactions with Materials and Atoms 58, 85-97.

Refait, P., Memet, J.B., Bon, C., Sabot, R., Génin, J.M.R. (2003) Formation of the $\mathrm{Fe}$ (II)-Fe(III) hydroxysulphate green rust during marine corrosion of steel. Corrosion Science 45, 833-845.

STOOKEY, L.L. (1970) Ferrozine---a new spectrophotometric reagent for iron. Analytical Chemistry 42, 779-781.

Trolard, F., Génin, J.M.R., Abdelmoula, M., Bourrié, G., Humbert, B., Herbillon, A. (1997) Identification of a green rust mineral in a reductomorphic soil by Mossbauer and Raman spectroscopies. Geochimica et Cosmochimica Acta 61, 1107-1111.

Wu, W., Swanner, E.D., Hao, L., Zeitvogel, F., Obst, M., Pan, Y., KAPPLER, A. (2014) Characterization of the physiology and cellmineral interactions of the marine anoxygenic phototrophic Fe(II) oxidizer Rhodovulum iodosum - implications for Precambrian Fe(II) oxidation. FEMS Microbiology Ecology 88, 503-515.

XIONG, J. (2007) Photosynthesis: what color was its origin? Genome Biology $7,245$.

Zegeye, A., Bonneville, S., Benning, L.G., Sturm, A., Fowle, D.A., Jones, C., Canfield, D.E., Ruby, C., Maclean, L.C., NomosaTRYO, S., POULTON, S.W., Crowe, S.A. (2012) Green rust formation controls nutrient availability in a ferruginous water column. Geology $40,599-602$ 